\title{
AUDIT OPERASIONAL ATAS FUNGSI PRODUKSI PERUSAHAAN (STUDI KASUS PADA PT. JAYA BRIX INDONESIA)
}

\author{
Rosdiyati \\ Fakultas Ekonomi, Universitas Islam Lamongan
}

\begin{abstract}
ABSTRAK
Penelitian ini bertujuan untuk mengetahui 1) pelaksanaan fungsi produksi telah sesuai dengan standar fungsi produksi yang telah ditetapkan pada perusahaan PT. Jaya Brix Indonesia. 2) mengetahui fungsi produksi PT. Jaya Brix Indonesia melakukan perencanaan dalam mencapai tujuan produksi. Metode penelitian yang digunakan adalah metode analisis deskriptif dengan pendekatan studi kasus yaitu metode dilakukan dengan cara mengumpulkan, menyajikan, menganalisis dan menginterpretasikan data secara sistematis sehingga dapat memberikan gambaran yang cukup jelas atas objek yang diteliti sehingga dapat dihasilkan suatu kesimpulan yang dijadikan dasar untuk memberikan saran. Hasil penelitian ini adalah 1) aktivitas fungsi produksi mulai dari jadwal induk produksi, penilaian atas tingkat persediaan, jadwal maintance, produktivitas dan nilai tambah, peralatan dan fasilitas produksi, pengendalian kualitas dan pengendalian barang jadi secara umum telah dilaksanakan dengan baik.2) secara umum aktivitas fungsi produksi telah efektif namun ada terdapat beberapa permasalahan.Sehingga perusahan perlu memperbaiki kekurangankekurangan yang ada agar kedepannya operasional produksi bisa efektif.
\end{abstract}

Kata kunci: audit operasional, fungsi produksi, efektivitas.

\section{PENDAHULUAN}

Pada 2015 ini negara Indonesia mulai dilaksankannya perdagangan bebas dalam regional ASEAN, yang mana perdagangan barang dari negaranegara ASEAN bebas memasuki wilayah tertentu negara Indonesia.Secara tidak langsung menyebabkan tingkat persaingan usaha semakin sulit dan ketat.

Persaingan dalam dunia usaha menuntut perusahaan harus mempunyai keunggulan bersaing agar mampu berkompetitif dengan perusahaan yang lainnya.Faktor desain, mutu barang, pengembangan produk, input teknologi, nilai tambah, harga, penyerahan tepat waktu dan layanan purna jual sangat menentukan keunggulan daya saing suatu perusahaan.dalam hal ini mengharuskan suatu perusahaan dapat mengambil keputusan yang cepat dan tepat untuk memungkinkan 
kelangsungan hidup dan pertumbuhan usaha perusahaan.

Pihak manajemen perusahaan dituntut untuk lebih bertanggung jawab agar cepat tanggap dalam menghadapi permasalahan yang nantinya akan menghambat kegiatan operasional perusahaan. Perusahaan harus memiliki alat yang mampu mengukur seberapa baik penggunaan sumber daya yang dimilikinya untuk mengelola manajemen agar dapat mencapai tujuan yang telah ditetapkan. Alat yang dimaksud adalah pemeriksaan atau audit operasional.

Audit operasional merupakan pemeriksaan terhadap kegiatan operasi suatu perusahaan, termasuk kebijakan akuntansi dan kebijakan operasional yang telah ditentukan manajemen untuk mengetahui apakah kegiatan operasi tersebut sudah dilakukan secara efektif, efisien, dan ekonomis (Agoes, 2012:158). Dari aktifitas ini akan memberikan manfaat bagi kontinuitas perusahaan karena dapat menunjang kelangsungan dari proses produksi perusahaan.

Audit operasional dapat dilaksanakan oleh berbagai macam perusahaan manufaktur. Dalam menjalankan kegiatan operasionalnya, perusahaan industri tidak terlepas dari proses produksi karena bagian produksi merupakan faktor penentu keberhasilan perusahaan. Masalah umum sebuah perusahaan dalam pengelolaan proses produksinya adalah rendahnya tingkat pengawasan fungsi produksi dan rendahnya pengawasan atas standar dan target yang ditetapkan, sehingga proses produksi tidak berjalan dengan maksimal dan target awal yang ditetapkan perusahaan tidak dapat tercapai dengan baik. Pada penelitian ini, audit operasional atau dikenal dengan istilah pemeriksaan manajemen difokuskan pada fungsi produksi di PT. Jaya Brix Indonesia, yang kegiatannya adalah memproduksi batu bata ringan (ACC Block) dan Papan Semen (Mega Board).

Pemeriksaan yang berkesinambungan perlu dilakukan guna mengetahui efisiensi dan efektifitas proses produksi. Tujuan audit operasional adalah untuk mengevaluasi kinerja, mengidentifikasi kesempatan untuk peningkatan, dan membuat rekomendasi untuk perbaikan atau tindakan lebih lanjut. Sehingga membantu manajer agar tanggung jawab masing-masing bagian dapat dilaksanakan secara efisien dan efektif. 
Berdasarkan pemikiran tersebut, penulis tertarik untuk meneliti audit operasional dengan ruang lingkup penelitian dibatasi pada kegiatan produksi dan mencoba menuangkannya dalam skripsi dengan judul : "Audit Operasional Atas Fungsi Produksi Perusahaan" ( Suatu studi pada PT.Jaya Brix Indonesia, Kemantren, Paciran, Lamongan).

Tujuan dari penelitian adalah untuk mengetahui pelaksanaan fungsi produksi telah sesuai standar fungsi produksi yang telah ditetapkan oleh PT. Jaya Brix Indonesi dan untuk mengetahui efektivitas aktivitas fungsi produksi PT. Jaya Brix Indonesia.

\section{TINJAUAN PUSTAKA}

\subsection{Audit Operasional}

Audit adalah suatu proses sistematik untuk memperoleh dan mengevaluasi bukti secara objektif mengenai mengenai pernyataan-pernyataan tentang kegiatan dan kejadian ekonomi dengan tujuan untuk menetapkan tingkat kesesuaian antara pernyatan-pernyataan tersebut dengan kriteria yang ditetapkan serta penyampaian hasil-hasilnya kepada pemakai yang berkepentingan.

Untuk jenis-jenis audit dibagi menjadi 3 yaitu: audit laporan keuangan, audit kepatuhan dan audit operasional. Pada penelitian ini lebih ke audit operasional atau istilah lain audit manajemen. Pengertian dari audit operasional menurut Bayangkara (2014:2) adalah pengevaluasian terhadap efisiensi dan efektivitas operasi perusahaan. Ruang lingkup audit operasional meliputi seluruh aspek kegiatan operasional seperti kegiatan, aktivitas, program dan bidang-bidang dalam perusahaan yang diketahui atau diidentifikasi masih memerlukan perbaikan/ peningkatan baik segi ekonomisasi, efisiensi dan efektivitas. Sedangkan elemen pokok dalam tujuan audit yaitu 1) criteria adalah standar atau pedoman bagi setiap individu/ kelompok dalam melakukan aktivitasnya didalam perusahaan. 2) cause adalah tindakan yang dilakukan setiap individu/ kelompok dalam perusahaan. 3) effect adalah perbandingan antara penyebab penyebab dan kriteria.

Dalam melakukan audit operasional harus sesuai dengan tahapan-tahapan yang ada. Menurut Bayangkara (2014:178) ada lima tahapan audit operasional yaitu 1) survey pendahuluan diawali dengan perkenalan antara pihak auditor dengan organisasi auditee, mengkonfirmasi scope audit, 
mendiskusikan rencana audit, mengenal lebih lanjut perusahaan dan mempelajari prosedur yang diterapkan pada proses produksi. 2) review dan pengujian pengendalian manajemen. Tahap ini auditor melakukan review dan pengujian terhadap beberapa perubahan yang terjadi pada struktur perusahaan, sistem manajemen kualitas, fasilitas yang digunakan dan atau personalia kunci dalam perusahaan, sejak hasil audit terakhir. Dan juga mengidentifikasi, mengklasifikasikan peyimpangan dan gangguan-gangguan yang terjadi yang mengakibatkan terhambatnya pencapaian tujuan produksi dan operasi. 3) audit lanjutan. Tahap ini auditor melakukan audit yang lebih dalam dan pengembangan temuan terhadap fasilitas, prosedur, catatan-catatan (dokumen) yang berkaitan dengan produksi dan operasi. Konfirmasi kepada pihak perusahaan selama audit dilakukan untuk mendapat penjelasan dari pejabat yang berwewenang tentang adanya halhal yang merupakan kelemahan (nonconformance) yang ditemukan auditor. Di samping itu, analisis terhadap hubungan kapabilitas potensial yang dimiliki dan utilisasi kapabilitas tersebut di dalam perusahaan sangat penting dalam proses audit. 4) pelaporan. Hasil dari keseluruhan tahapan audit sebelumnya telah diringkaskan dalam kertas kerja audit (KKA), merupakan dasar dalam membuat kesimpulan audit dan rumusan rekomendasi yang akan diberikan auditor sebagai alternatif solusi atas kekurangan-kekurangan yang masih ditemukan. 5) tindak lanjut. Rekomendasi auditor dalam laporannya merupakan alternatif perbaikan yang ditawarkan untuk mengingkatkan berbagai kelemahan yang masih terjadi pada perusahaan.Tindak lanjut yang dilakukan merupakan komitmen manajemen untuk menjadikan perusahaannya menjadi yang lebih baik dari sebelumnya.

\subsection{Fungsi Produksi}

Secara umum fungsi produksi terkait dengan pertanggung jawaban dalam pengolahan dan pentransformasian masukan (input) menjadikeluaran (output) berupa barang dan jasa yang akan dapat memberikanhasil pendapatan bagi perusahaan. Empat fungsi terpenting dalam fungsi produksi dan operasi adalah : proses pengolahan, jasa-jasa penunjang, perencanaan, dan pengendalian atau pengawasan. 
Audit operasional atas fungsi produksi dan operasi , dengan melakukan penilaian secara komprehensif keseluruhan fungsi produksi dan operasi untuk menentukan apakah fungsi ini telah berjalan dengan memuaskan (ekonomis, efektif, dan efisien). Audit ini dilakukan tidak hanya terbatas pada unit produksi tetapi juga berlaku untuk keseluruhan proses produksi dan operasi. Audit ini juga berperan melengkapi fungsi pengendalian kualitas. Ruang lingkup audit operasional fungsi produksi dan operasi yaitu menilai tentang rencana produksi dan operasi, produktivitas dan nilai tambah, pengendalian peralatan dan fasilitas produksi, pendendalian kualitas serta pengeendalian barang jadi.

\section{METODOLOGI PENELITIAN}

Desain atau rancangan penelitian ini menggunakan metode deskriptif kualitatif.Penelitian ini dengan pendekatan studi kasus, yaitu meneliti suatu permasalahan dalam perusahaan kemudian dibandingkan dengan teoriteori yang ada.Menurut Sugiyono (2014:23) menyatakan bahwa data kualitatif yaitu data yang diperoleh dalam bentuk informasi, baik secara lisan maupun tulisan yang berkaitan dengan masalah yang diteliti.

Populasi dalam penelitian ini adalah aktivitas semua karyawan di PT. Jaya Brix Indonesia.Sedang penelitian ini mengambil sampel SOP (Standar Operasional Produksi) departemen papan semen. Adapun dalam penelitian ini terdapat variabel-variabel operasi sebagai berikut : audit operasional, proses produksi dan efektivitas.

Analisis data merupakan proses penyerdehanaan data ke dalam bentuk yang mudah dibaca, dipahami, dan diinterpretasikan. Pengolahan data dilakukan dengan teknik analisis deskripsi kualitatif. Teknik ini memberikan ulasan atau memaparkan data yang diperoleh menjadi lebih jelas dalam bentuk narasi. Langkah-langkah dari teknik ini adalah dengan mereduksi data dari data yang peneliti dapatkan dari hasil wawancara, kuesioner dan kajian literatur. Proses reduksi data adalah pengurangan data melalui codingdan kategorisasi. Coding adalah proses analitik dimana data kualitatif yang telah dikumpulkan akan dikurangi, diatur ulang, dan integrasikan. Tujuan pengkodean adalah untuk membantu peneliti untuk menarik kesimpulan dari data hasil wawancara, kuesioner 
dan kajian literatur. Setelah proses pengkodean selesai maka peneliti melakukan klasifikasi terhadap coding yang telah dilakukan agar mengetahui sejauh mana makna atau kesimpulan dari data yang didapatkan sesuai dengan tujuan dari penelitian. Kemudian, peneliti melakukan proses kategorisasi yang merupakanproses pengorganisasian, mengatur, dan mengklasifikasi unit coding. Sehingga makna atau kesimpulan yang telah peneliti dapatkan dengan kategori yang ada akan dihubungkan satu dengan yang lainnya. Setelah dilakukan proses reduksi data maka langkah yang berikutnya adalah data display. Data display merupakan penyajian data dengan bagan, diagram, bahkan teks dengan tujuan untuk mempermudah peneliti memahami data yang telah didapatkan, Kemudian langkah terakhir dalam teknik analisis deskripsi adalah penarikan kesimpulan. Menurut Sekaran dan Bougie (2009:382-383),

Conclusion drawing is the "final" analytical activity in the process of qualitative data analysis. It is the essence of data analysis; it is at this point where you answer your researcher questions by determining what identified themes stand for, by thinking about explanations for observed patterns and relationships, or by making contrasts and comparisons.

Dalam penelitian kualitatif, penarikan kesimpulan merupakan kegiatan terakhir dari menganalisis data. Dalam hal ini peneliti memberikan penjelasan mengenai data yang telah dikumpulkan baik data primer maupun data sekunder dan menghubungkannya dengan rumusan masalah yang telah peneliti tetapkan sebelumnya atau dengan membuat sebuah perbandingan.

\section{HASIL PENELITIAN DAN PEMBAHASAN}

\subsection{Audit Manajemen atas Fungsi Produksi}

Laporan Audit Manajemen Atas Fungsi Produksi pada PT. Jaya Brix Indonesia adalah sebagai berikut:

1. Survey pendahuluan

Pelaksanaan survei pendahuluan yang telah dilakukan untuk memperoleh informasi mengenai fungsi produksi pada PT. Jaya Brix Indonesia adalah sebagai berikut: mendapatkan informasi umum mengenai perusahaan seperti profil perusahaan, tujuan umum perusahaan, dan menjelaskan secara garis besar 
penelitian yang akan dilaksanakan. Mengumpulkan data dan informasi meliputi sejarah perusahaan, struktur organisasi, visi dan misi perusahaan, proses produksi, observasi langsung kondisi perusahaan dan membagikan kuesioner untuk menilai penetapan tujuan produksi perusahaan PT. Jaya Brix Indonesia.

2. Review dan pengujian pengendalian manajemen

Mereview atas kuesioner yang telah dibagikan dan penilaian penetapan tujuan produksi

a) Penilaian rencana induk produksi

Departemen produksi telah melaksanakan proses produksi dan rencana induk produksi telah sesuai dengan standar yang telah ditentukan peusahaan dan menyusun rancangan anggaran produksi serta perencanaan untuk mencapai tujuan dan target produksi dengan menyusun skedul produksi maupun bahan baku. Departemen produksi juga telah menyusun laporan produksi harian.Kelemahan yang didapatkan, rencana induk produksi dalam mensosialisasikan prosedur pengendalian persediaan masih kurang efektif sebab masih terdapat karyawan yang belum memahami sepenuhnya tentang prosedur tersebut. Dalam pencapaian target produksi belum maksimal itu disebabkan karena dalam proses produksi kadang terjadi permasalahan dan mesin yang digunakan mengalami trouble.

b) Penilaian produktivitas dan nilai tambah

Perusahaan telah memiliki standar produktivitas yang dijadikan sebagai pedoman oleh karyawan bagian produksi dan perusahaan juga telah memberikan tanggung jawab kepada karyawan dalam merencanakan, melaksanakan, dan mengendalikan aktivitasnya masing-masing. Kelemahan yang didapat adalah masih sering terjadi pengerjaan ulang, pemborosan bahan dan kegagalan produk dalam memenuhi spesifikasi standar produk yang harus dicapai.

c) Peralatan dan fasilitas produksi

Semua peralatan yang digunakan dalam proses produksi telah sesuai dengan ukuran dan desain yang telah ditentukan serta lokasi penempatan peralatan sangat efektif dan efisien sesuai dengan 
kebutuhan proses. Terdapat prosedur tertulis dalam penggunaan peralatan proses produksi tetapi belum teradapat instruksi tertulis pemeliharaan dan perawatan produksi.

d) Pengendalian kualitas

Perusahaan telah memiliki pedoman pengendalian kualitas secara tertulis tetapi masih terdapat beberapa karyawan produksi yang masih belum mengetahui atau mendapatkan salinan kebijakan pengendalian kualitas.Perusahaan juga memberikan pelatihan dalam rangka peningkatan kualitas karyawan tetapi diakui oleh karyawan masih jarang dilakukan.

e) Pengendalian barang jadi

Pengendalian barang jadi maksudnya produk akhir dari papan semen yang akandijual ke customer akan dipisahkan dengan produk yang belum selesai. Produk yang cacat akan diproses lagi / dipotong kembali sehingga tidak ada yang terbuang. Produk yang cacat tersebut akan diolah kembali menjadi papan semen dengan jenis yang berbeda (jenis reject). Kelemahan yang ada yaitu tidak produk yang pertama diproduksi untuk dikirim terlebih dahulu ke customer.

Kekuatan-kekuatan dalam pengendalian manajemennya adalah sebagai berikut:

1. Perusahaan memiliki struktur organisasi yang cukup jelas yang mengukur tentang wewenang, tugas dan tangung jawab masing-masing bagian.

2. Perusahaan telah memiliki standar operasional produksi yang baik, hal tersebut dapat memudahkan bagian pengawasan memantau jalannya proses produksinya.

3. Perusahaan memiliki pabrik dan gudang yang baik dan rapi. Mesinmesin yang digunakan dalam proses produksi disusun berdasarkan process lay-out dimana penyusunan dilakukan dengan mengelompokkan mesinmesin yang memiliki fungsi sama pada satu tempat. Peyimpanan persediaan juga pada tempat yang memadai.

4. Pengecekan terhadap kualitas bahan baku yang akan digunakan sebelum melakukan proses produksi dilakukan oleh quality control untuk menjamin bahan baku sesuai dengan kriteria kualitas yang telah ditetapkan. 
3. Audit terinci

Berdasarkan hasil dari evaluasi atas fungsi produksi pada PT. Jaya Brix Indonesia, berikut disusun tujuan dan prosedur audit yang dapat digunakan untuk melaksanakan tahap audit terinci.

\subsection{Pemeriksaan atas Perencanaan Produksi}

Tujuan audit terhadap perencanaan produksi adalah untuk menilai apakah perencanaan produksi yang ditetapkan oleh perusahaan telah efektif, efisien dan ekonomis serta mengevaluasi pencapaian tersebut.

Prosedur audit terhadap perencanaan produksi adalah sebagai berikut:

a. Memperoleh informasi mengenai apakah perusahaan memiliki perencanaan produksi tiap tahunnya.

b. Memperoleh informasi mengenai standar yang telah ditetapkan perusahaan dalam merencanakan produksi tahunan.

c. Mengevaluasi apakah rencana produksi telah didukung dengan tersedianya bahan baku untuk proses produksi.

d. Membuat simpulan audit.

\subsection{Pemeriksaan atas Pelaksanaan Produksi}

Tujuan audit terhadap pelaksanaan produksi adalah untuk menilai proses produksi pada perusahaan telah berjalan sesuai dengan perencanaan produksi sehingga dapat tercapai efektivitas dan efisiensi dalam produksi.

Prosedur audit terhadap pelaksanaan produksi adalah sebagai berikut:

a. Melakukan wawancara mengenai prosedur produksi yang telah ditetapkan perusahaan.

b. Memahami prosedur dan cara kerja produksi perusahaan.

c. Mengevaluasi apakah proses produksi yang dilaksanakan sesuai dengan standar produksi perusahaan.

d. Mengevaluasi apakah perusahaan telah mampu mengendalikan proses produksi yang dijalankan perusahaan.

e. Membagikan kuesioner kepada bagian produksi yang terkait dengan proses produksi dan mengevaluasi jawaban kuesioner.

f. Membuat simpulan audit.

\subsection{Pelaporan audit}

Laporan hasil audit operasional adalah sebagai berikut: 
1) Perencanaan target produksi masih kurang efektif

\section{Kondisi:}

Berdasarkan hasil evaluasi kuesioner yang dilakukan, diketahui bahwa PT. Jaya Brix Indonesia dalam merencanakan produksinya masin kurang efektif. Hal ini diakui oleh beberapa karyawan bagian produksi itu sendiri. Para karyawan mengatakan masih kurang efektif dikarenakan sering terjadinya kemacetan (Trouble) dalam penggunaan mesin produksi pada waktu proses produksi. Ketika terjadi listrik padam mesin otomatis akan berhenti karena mengikuti aliran listrik yang ada sehingga menunggu bagian listrik menghidupkan mesin janset.

\section{Kriteria:}

Seharusnya perusahaan mencermati permasalahan yang ada dalam proses produksi seperti terjadi kemacetan yang dapat menggangu kelancaran produksivitas.

\section{Akibatnya: \\ Produk yang dihasilkan tidak efektif dalam memenuhi target yang direncankan sebelumnya.}

\section{Rekomendasi:}

Sebaiknya perusahaan melakukan perencanaan terlebih dahulu, sebelum memulai beraktivitas melakukan operasi produksi, dilakukan toolbox meeting supaya manajer mengetahui kendala-kendala yang sebelumnya terjadi dan melakukan evaluasi agar bisa menemukan solusi dari kendala yang terjadi sebelumnya. Selain itu setiap departemen dan operator yang berhubungan dengan produksi bisa menyiapkan yang dibutuhkan dengan baik dan bisa tanggap dalam mengatasi masalah yang nantinya bisa terjadi sewaktu-waktu. Sehingga jalannya proses produksi bisa efektif dan mampu memenuhi target yang direncanakan.

2) Sering terjadi pengerjaan ulang, pemborosan bahan baku dan kegagalan produk dalam memenuhi spesifikasi standar produk yang harus dicapai.

\section{Kondisi:}

Setiap produk yang akan diproduksi memiliki standar spesifikasi produk masing-masing yang harus dicapai atau telah dinyatakan lulus uji akhir 
sehingga produk tersebut siap dijual ke pasaran. Ternyata ada beberapa produk yang gagal atau tidak memenuhi standar kualitas produk sehingga harus dilakukan pengerjaan ulang yang mengakibatkan adanya pemborosan bahan baku dan waktu.

\section{Kriteria:}

Seharusnya tidak ada terjadinya kegagalan produk dalam memenuhi standarspesifikasi sehingga tidak terjadi pengerjaan ulang yang mengakibatkan pemborosan bahan baku dan waktu.

\section{Sebab:}

Terjadinya kegagalan produk yang dihasilkan karena tidak sesuai dengan spesifikasi produk sehingga dilakukan pengerjaan ulang terhadap produk gagal tersebut. Seringkali produk yang dihasilkan tidak sesuai dengan ukuran atau terjadi goresan pada papan semen yang mengakibatkan papan semen rusak (pecah).

\section{Akibat:}

Pada saat akan dilakukan pemeriksaan sebelum produk dipasarkan ditemukan adanya beberapa produk yang tidak sesuai atau tidak memenuhi standar kualitas produk. Hal ini mengakibatkan produk papan semen tersebut tidak dapat dijual kepasaran sehingga adanya pengerjaan ulang terhadap produk tersebut. Pengerjaan ulang terhadap produk gagal inilah yang berdampak adanya pemborosan bahan baku dan waktu.

\section{Rekomendasi:}

$\begin{array}{rrr} & \text { Sebaiknya } & \text { peralatan yang } \\ \text { ada } & \text { harus } & \text { dimaksimalkan }\end{array}$ penggunaannya atau ada beberapa peralatan yang harus diperbaiki yang seringkali membuat kemacetan. Dengan memiliki peralatan yang bekerja secara efisien dan efektif akan menghasilkan produk papan semen dengan kualitas yang terbaik. Dengan demikian, diharapkan mengurangi kemungkinan adanya kegagalan produk yang berujung pada pengerjaan ulang produk. 
3) Tidak adanya instruksi tertulis mengenai pemeliharaan dan perawatan peralatan produksi.

\section{Kondisi:}

Perusahaan tidak memiliki instruksi tertulis atau prosedur tertulis dalam pemeliharaan dan jadwal perawatan setiap peralatan. Sehingga karyawan tidak mengetahui secara pasti untuk merawat atau membersihkan setiap peralatan produksi (intensitas perawatan dan pemeliharaan peralatan).

\section{Kriteria:}

Seharusnya di setiap peralatan memiliki prosedur tertulis pemeliharaan dan perawatan sehingga karyawan mengetahui kapan waktu dan bagaimana cara merawat dan memelihara peralatan yang ada sehingga dapat menjaga umur ekonomis peralatan yang ada.

\section{Sebab:}

Tidak adanya prosedur tertulis yang dibuat atau ditetapkan oleh perusahaan. Hal ini dikarenakan mungkin pimpinan beranggapan bahwa pemeliharaan dan perawatan peralatan produksi dapat diberitahukan secara lisan dari manajer produksi ke karyawan produksi.Sehingga tidak diperlukan prosedur secara tertulis karena pemberitahuan secara lisan dirasa cukup memadai.

\section{Akibat: \\ Dengan tidak adanya prosedur tertulis maka karyawan seakan tidak peduli untuk merawat dan memelihara peralatan produksi yang digunakan. Walaupun dengan adanya pemberitahuan secara lisan dapat terjadinya kemungkinan penyimpangan atau kesalahan dalam pemeliharaan dan perawatan peralatan produksi yang dapat merusak peralatan yang ada.}

\section{Rekomendasi:}

Sebaiknya ditetapkan dan dibagikan prosedur tertulis kepada setiap karyawan yang terkait langsung dengan proses produksi sehingga peralatan dapat digunakan secara efektif dan efisien. Dapat juga ditempelkan dibagian sisi setiap peralatan sehingga karyawan dapat membacanya dengan seksama. 
4) Salinan kebijakan kualitas tidak diberikan kepada semua karyawan produksi yang terkait.

\section{Kondisi:}

Perusahaan memiliki salinan kebijakan kualitas tetapi salinan tersebut hanya diberikan satu pada setiap departemen yang mengakibatkan adanya asimetri informasi. Karyawan yang terkait langsung dengan proses produksi tidak mengetahui secara pasti mengenai kualitas setiap produk yang ingin dicapai oleh perusahaan.

\section{Kriteria:}

Perusahaan harus memberikan informasi yang sama mengenai standar kualitas setiap produk kepada setiap karyawan produksi yang terkait langsung dengan proses produksi. Dengan begitu, karyawan mampu mengawasi jalannya proses produksi agar mengurangi adanya kemungkinan kegagalan produk.

\section{Sebab:}

Tidak adanya pembagian salinan kebijakankualitas yang diberikan kepada setiap karyawan produksi yang terkait langsung dalam proses produksi. Hal ini dikarenakan setiap departemen terutama departemen produksi hanya memiliki satu salinan kebijakan kualitas.

\begin{abstract}
Akibat:
Dengan tidak adanya salinan kebijakan kualitas yang dipegang oleh setiap karyawan yang berhubungan langsung dengan produksi mengakibatkan kemungkinan adanya kegagalan produk. Hal ini dikarenakan karyawan yang tidak mengetahui mengenai masalah kualitas sehingga kurangnya pengawasan terhadap produk.
\end{abstract}

\section{Rekomendasi:}

Sebaiknya setiap karyawan yang berkaitan langsung dengan proses produksi diberikan salinan kebijakan kualitas sehingga ada pengawasan atau pengendalian yang mampu dilakukan selama proses produksi. Dengan adanya salinan yang dipegang oleh karyawan produksi memungkinkan tidak terjadinya kegagalan produk.

5) Tidak adanya prosedur tertulis pengelolaan stok untuk memastikan 
barang produksi pertama dijual terlebih dahulu.

\section{Kondisi:}

Perusahaan tidak membuatkan prosedur tertulis pengelolaan stok barang yang akan dijual, biasanya barang yang akan dijual diambil dari barang yang ditumpuk paling atas karena memudahkan pekerjaan.

\section{Kriteria:}

Seharusnya dibuatkan prosedur tertulis tentang pengelolaan stok agar tidak terjadi penumpukan barang terlalu banyak dan memastikan produk yang pertama kali dibuat untuk diperjualkan.

\section{Sebab:}

Tidak adanya prosedur mengenai pengelolaan stok. Pimpinan beranggapan yang memudahkan pekerjaan karyawan barang yang diambil untuk dijual, dengan memudahkan pekerjaan karyawan waktu yang dibutuhkan akan efisien.

\section{Akibat:}

Dengan tidak adanya prosedur tertulis tentang pengelolaan stok yang akan dijual, barang produk bisa rusak karena karyawan ingin pekerjaannya cepat selesai dalam memindahkan produk papan semen ke truk pengangut untuk dijual. Produk pertama yang diproduksi sering diletakkan dibagian bawah dan ditumpuki produk yang diproduksi selanjutnya. Dengan penumpukan sesering produk yang pertama diletakkan paling bawah akan mengalami kerusakan.

\section{Rekomendasi:}

Seharusnya dibuatkan dan ditetapkannya pengelolaan stok atas barang yang akan dijual. Mendahulukan produk atau barang yang pertama diproduksi terlebih dahulu dan meletakkan produk awal diproses di atas produk yang baru diproduksi.

\section{PENUTUP}

\subsection{Simpulan}

Berdasarkan hasil penelitian dengan melakukan tahap-tahap audit operasional disertai dengan melakukan analisis data dengan dilandasi dengan teori yang relevan dengan masalah yang diteliti pada PT.Jaya Brix Indonesia, maka peneliti mengambil kesimpulan sebagai berikut: pelaksanaan fungsi produksi 
telah sesuai dengan standar fungsi produksi yang telah ditetapkan oleh manajemen perusahaan PT. Jaya Brix Indonesia. Hal ini terlihat dari ruang lingkup penilaian penetapan tujuan produksi; untuk penilaian rencana induk produksi pada PT. Jaya Brix Indonesia telah melaksanakan proses produksi sesuai dengan standar yang ditentukan oleh perusahaan, memiliki perencanaan produksi yang disusun beserta anggaran yang dibutuhkan dan membuat skedul produksi terlebih dahulu serta memiliki perencanaan bahan baku. Akan tetapi, ditemukan target produksi yang telah ditetapkan masih belum efektif dikarenakan sering terjadi trouble pada mesin yang digunakan dalam proses produksi.

Produktivitas dan nilai tambah pada PT. Jaya Brix Indonesia, perusahaan telah memiliki standar produktivitas yang dijadikan sebagai pedoman oleh karyawan bagian produksi dan perusahaan juga telah memberikan tanggung jawab kepada karyawan dalam merencanakan, melaksanakan, dan mengendalikan aktivitasnya masingmasing. Kelemahan yang didapatkan adalah sering terjadinya pengerjaan ulang, pemborosan bahan dan kegagalan produk dalam memenuhi spesifikasi standar produk yang harus dicapai. Untuk Peralatan dan fasilitas produksi yang dimiliki oleh PT. Jaya Brix Indonesia. Semua peralatan yang digunakan dalam proses produksi telah sesuai dengan ukuran dan desain yang telah ditentukan. Peralatan dan fasilitas produksi yang ada cukup efisien tetapi ada beberapa peralatan yang belum terdapat instruksi tertulis pemeliharaan dan perawatan peralatan produksi. Sehingga diharapkan dengan adanya instruksi tertulis pada setiap peralatan maka efisiensi dan efektivitas peralatan dapat dirasakan jangka panjang.

Pengendalian kualitas PT. Jaya Brix Indonesia telah memiliki pedoman pengendalian kualitas secara tertulis dan telah memberikan pelatihan pada karyawannya. Pengendalian cukup efisien tetapi masih terdapat beberapa karyawan produksi yang belum mengetahui atau mendapatkan salinan kebijakan pengendalian kualitas.Untuk Pengendalian barang jadi PT. Jaya Brix Indonesia. Perusahaan sudah memisahkan antara produk yang siap dijual dengan produk akhir agar tidak terjadi kekeliruan.Perusahaan tidak memiliki prosedur tertulis tentang pengelolaan stok penanganan pengiriman barang. Namun Produk yang 
cacat akan diolah kembali menjadi papan semen yang baru atau menjadi jenis reject. Pengendalian barang jadi pada perusahaan sudah efisien, efektif, dan ekonomis karena walaupun terjadi kegagalan produk, perusahaan tetap mampu mengolah kembali tanpa membuang papan semen yang tidak memenuhi standar spesifikasi untuk dijual.

Secara umum aktivitas fungsi produksi telah efektif namun demikian masih terdapat beberapa permasalahan pada aktivitas jadwal induk produksi, produktivitas dan dilai tambah yang menyebabkan pemborosan bahan baku dan pengerjaan ulang produk, serta tidak adanya prosedur pengendalian barang jadi perlakuan pengiriman barang.

\subsection{Saran}

Perusahaan sebaiknya melakukan perencanaan terlebih dahulu, sebelum memulai aktivitas proses produksinya, dilakukan toolbox meeting supaya semua karyawan mengetahui kendalakendala yang sebelumnya terjadi, mengevaluasi dan mengantisipasinya agar tidak mengalami kendala lagi.Bagian teknisi selalu mengontrol jalannya mesin produksi selama kegiatan produksi berlangsung. Selain itu setiap departemen dan operator yang berhubungan dengan produksi bisa menyiapkan yang dibutuhkan dengan baik dan bisa tanggap dalam mengatasi masalah yang nantinya bisa terjadi sewaktu-waktu. Sehingga jalannya proses produksi bisa efektif danmampu memenuhi target yang direncanakan. Sebaiknya peralatan yang ada harus dimaksimalkan penggunaannya atau ada beberapa peralatan yang harus diperbaiki yang seringkali membuat kemacetan. Dengan memiliki peralatan yang bekerja secara efisien dan efektif akan menghasilkan produk papan semen dengan kualitas yang terbaik. Dengan demikian, diharapkan mengurangi kemungkinan adanya kegagalan produk yang berujung pada pengerjaan ulang produk.Sebaiknya ditetapkan dan dibagikan prosedur tertulis kepada setiap karyawan yang terkait langsung dengan proses produksi sehingga peralatan dapat digunakan secara efektif dan efisien. Dapat juga ditempelkan dibagian sisi setiap peralatan sehingga karyawan dapat membacanya dengan seksama.Sebaiknya setiap karyawan yang berkaitan langsung dengan proses produksi diberikan salinan kebijakan kualitas sehingga ada pengawasan atau pengendalian yang mampu dilakukan 
selama proses produksi. Dengan adanya salinan yang dipegang oleh karyawan produksi memungkinkan tidak terjadinya kegagalan produk.

Seharusnya dibuatkan dan ditetapkannya pengelolaan stok atas barang yang akan dijual. Mendahulukan produk atau barang yang pertama diproduksi terlebih dahulu dan meletakkan produk awal diproses di atas produk yang baru diproduksi.Perusahaan sebaiknya cepat megambil keputusan untuk mendukung dan menindak lanjuti rekomendasi yang dikemukakan oleh auditor agar permasalahan-permasalahan yang terjadi bisa diantisipasi dan membantu fungsi produksi kedepannya lebih efektif dalam melaksanakan aktivitasnya.

\section{DAFTAR PUSTAKA}

Agoes, Sukrisno. 2012. Auditing Petunjuk Praktis Pemeriksaan Akuntan oleh Akuntan Publik. Jakarta: Salemba Empat.

Agoes, Sukrisno. 2013. Bunga Rampai Auditing. Jakarta: Salemba Empat.

Bayangkara, IBK. 2008. Audit Manajemen: Prosedur dan
Implementasi. Jakarta: Salemba Empat.

Sekaran, U. dan Bougie. 2009. Research Methods for Business: A Skill Building Approach. John Wiley and Sons, Limited. Academic Internet Publishers Incorporated.

Sugiyono. 2014. Statistika untuk Penelitian. Bandung:Alfabeta. 